\title{
Kajian Potensi Vinase Sebagai Bahan Fertigasi Di Perkebunan Tebu (Saccharum Officinarum L.)
}

\author{
Vita Ayu Kusuma Dewi ${ }^{1 *}$, Rivandi Pranandita Putra ${ }^{2}$, Whisnu Febry Afrianto ${ }^{3}$ \\ ${ }^{1}$ Fakultas Teknik, Universitas Negeri Malang, Indonesia \\ ${ }^{2}$ Pusat Penelitian Perkebunan Gula Indonesia, Indonesia \\ ${ }^{3}$ Ecosystem and Biodiversity (Ecosbio), Indonesia \\ "Korespondensi: vita.ayu.kusuma.ft@um.ac.id
}

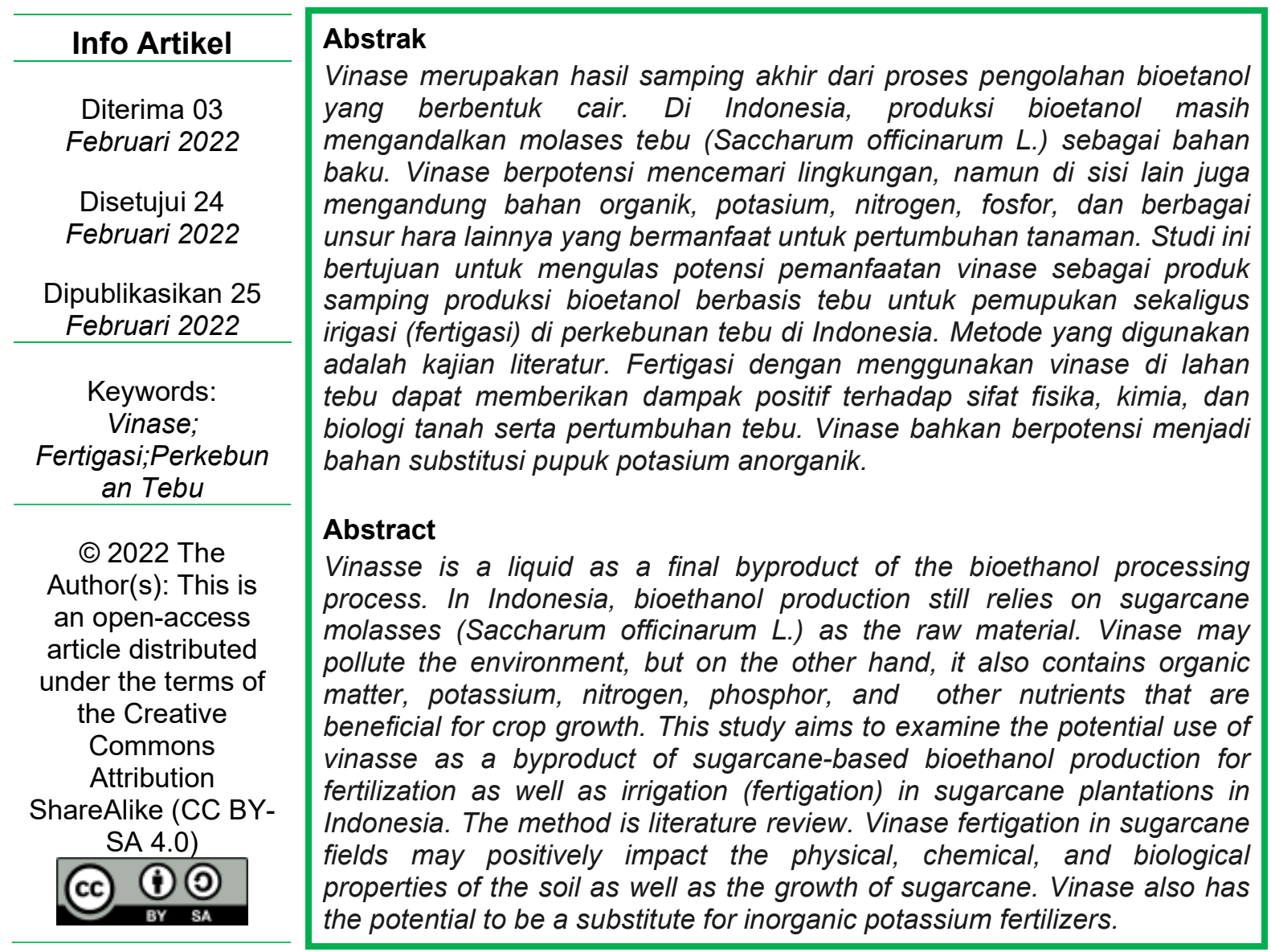

\section{Pendahuluan}

Bioetanol merupakan salah satu alternatif sumber energi selain bahan bakar fosil yang dibuat melalui proses fermentasi bahan-bahan alami oleh mikroorganisme (Jeon et al. 2007; Robak and Balcerek 2018). Beberapa material alami yang umum digunakan sebagai bahan dasar pembuatan bioetanol, antara lain tebu, jagung, singkong, gandum (Siles et al. 2011) dan masih banyak lagi sumber lainnya. Vinase umumnya dihasilkan dari produksi bioetanol berbasis tebu 
di Amerika Selatan (Hannon and Trenkle 1990), jagung dan tequila di Amerika Utara, serta bit, wine, dan buah-buahan di Eropa (España-Gamboa et al. 2011). Pada industri bioetanol berbasis tebu, bahan baku yang dapat digunakan berupa molases (tetes tebu), sari tebu (sugar juice), maupun campuran antara molases dan sari tebu (mixed must) (Gambar 1) (Gurgel et al. 2015; Prado, Caione, dan Campos 2013). Produksi bioetanol di Indonesia masih banyak memanfaatkan molases atau tetes tebu sebagai bahan baku (Aprinada et al., 2019). Setiap tahunnya, sekitar 450 juta liter bioetanol diproduksi di Indonesia menggunakan molases tebu (Khatiwada and Silveira 2017). Molases merupakan residu dari proses pengkristalan gula pasir di pabrik gula yang masih mengandung gula dan berbagai asam organik sehingga cocok untuk digunakan sebagai bahan baku pembuatan bioethanol (Adhitya et al., 2013). Molases mengandung 50\% gula sederhana yang dapat difermentasi secara langsung oleh ragi (yeast) menjadi bioetanol tanpa perlakuan pendahuluan (pre-treatment). Hasil bioetanol yang dibuat dari molases umumnya lebih tinggi dan waktu fermentasi yang dibutuhkan pun lebih singkat daripada bila menggunakan bahan lain (Umamaheswari et al. 2010). Kelebihan lain dari penggunaan molases sebagai bahan baku pembuatan bioetanol adalah mudah didapatkan dan dapat dibeli dengan biaya rendah (Nasution, Feliatra, and Effendi 2021; Senthilkumar et al. 2016; Umamaheswari et al. 2010).

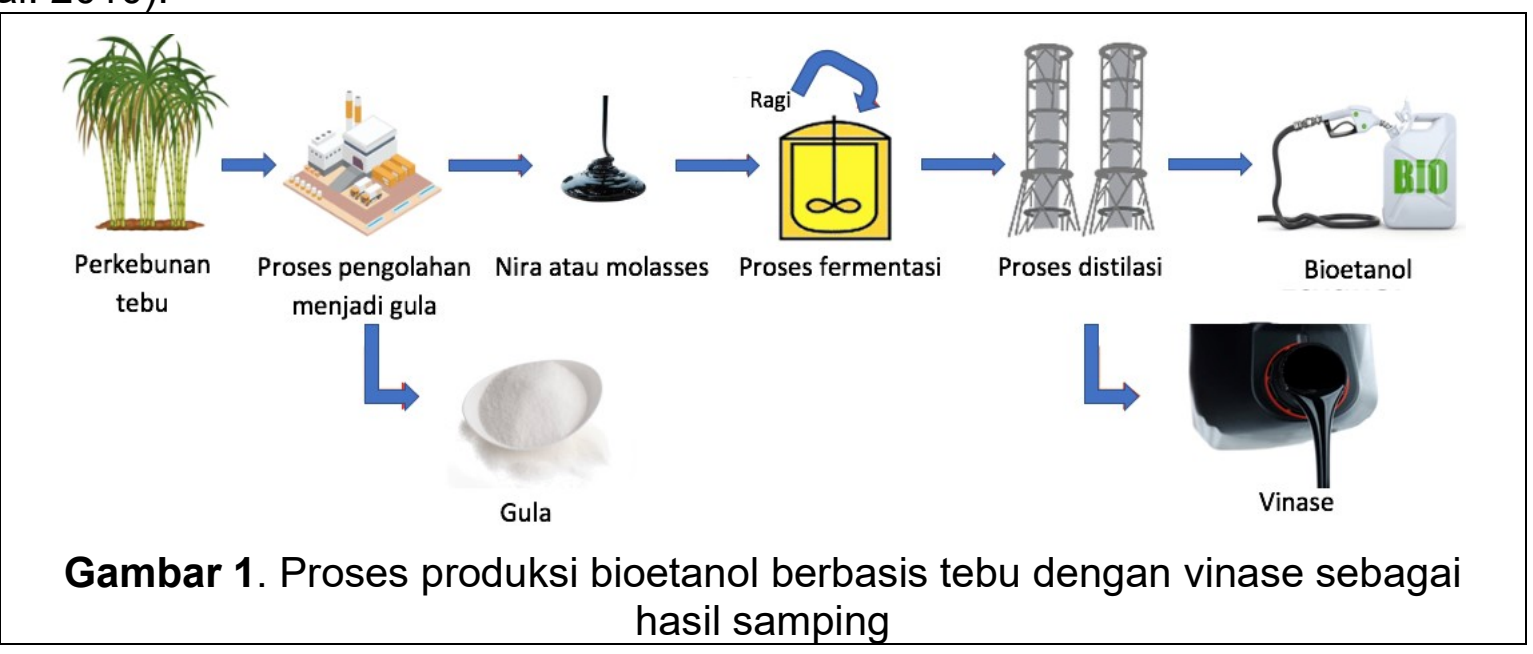

Produksi bioetanol berbahan baku tebu akan menghasilkan beberapa residu agroindustri, salah satunya yaitu vinase (stillage) yang berupa limbah cair (Bonomi et al. 2016; Gurgel et al. 2015). Dari satu liter produksi etanol, umumnya dihasilkan sekitar 8 hingga 15 liter vinase (Bonomi et al. 2016). Sumber lain mengatakan bahwa dari pembuatan satu liter etanol, akan dihasilkan 12-13 liter vinase (Martinelli and Filloso 2008). Vinase merupakan larutan asam berwarna cokelat kehitaman, memiliki kandungan chemical oxygen demand (COD) tinggi, mempunyai $\mathrm{pH}$ rendah, serta bersifat salin dan memiliki aroma tidak sedap (Christofoletti et al. 2013; Jiménez et al. 2006; Li et al. 2016; Valdés-Gómez et al., 2009). Umumnya vinase mengandung sulfat dalam jumlah tinggi, hal ini dikarenakan adanya penggunaan asam sulfur pada beberapa tahapan dalam proses produksi gula dan bioethanol (Fuess dan Garcia 2015). Selain itu, vinase juga mengandung berbagai komponen organik, sebagai asam asetat, asam laktat, fenol, gliserol, polifenol, dan melanioidin. Meskipun demikian, kandungan kimia dan karakter vinase dapat berbeda-beda antara satu sama lain dan hal tersebut sangat bergantung pada bahan baku yang digunakan, kondisi fermentasi, dan 
teknologi atau proses distilasi yang diterapkan (España-Gamboa et al. 2011; Gemtos, Chouliaras, and Marakis 1999; Naik, Jagadeesh, and Alagawadi 2008; Ortiz and Erazzú 2019; Yadav and Ann 2012). Hal ini dapat dilihat pada Tabel 1.

Tabel 1. Perbedaan karakteristik kimia vinase mentah yang dihasilkan dari beberapa material organik

\begin{tabular}{|c|c|c|c|c|c|c|c|c|}
\hline \multirow[t]{2}{*}{ Parameter } & \multicolumn{8}{|c|}{ Sumber bahan pembuatan vinase } \\
\hline & $\begin{array}{l}\text { Molases } \\
\text { tebu }\end{array}$ & $\begin{array}{l}\text { Nira } \\
\text { tebu } \\
\text { (cane } \\
\text { juice) }\end{array}$ & $\begin{array}{l}\text { Sorgum } \\
\text { manis }\end{array}$ & Bit & & Wine & $\begin{array}{l}\text { Wine } \\
\text { lees }\end{array}$ & Wortel \\
\hline $\begin{array}{l}\text { Bahan } \\
\text { organik (\%) }\end{array}$ & $\begin{array}{l}50,54 \\
(14)\end{array}$ & na & na & $\begin{array}{l}29- \\
34,17 \\
(2,11)\end{array}$ & & na & na & na \\
\hline $\mathrm{pH}$ & $\begin{array}{l}3,25-5,1 \\
(1,6,8,10,12, \\
13)\end{array}$ & $\begin{array}{l}3,75 \\
(7)\end{array}$ & $\begin{array}{l}4,5 \\
(3)\end{array}$ & $\begin{array}{l}4,5 \\
5,38 \\
(2,4,11)\end{array}$ & - & $\begin{array}{l}4,2 \\
(5)\end{array}$ & $\begin{array}{l}3,8 \\
(4)\end{array}$ & $\begin{array}{l}4,4 \\
(9)\end{array}$ \\
\hline COD (mg/L) & $\begin{array}{l}97000- \\
299250 \\
(6,8,10,13)\end{array}$ & $\begin{array}{l}68560 \\
(7)\end{array}$ & $\begin{array}{l}79900 \\
(3)\end{array}$ & na & & $\begin{array}{l}27500 \\
(5)\end{array}$ & $\begin{array}{l}122000 \\
(4)\end{array}$ & $\begin{array}{l}44000 \\
(9)\end{array}$ \\
\hline $\mathrm{BOD}(\mathrm{mg} / \mathrm{L})$ & $\begin{array}{l}33236- \\
36666 \\
(6,8,13)\end{array}$ & $\begin{array}{l}29700 \\
(7)\end{array}$ & $\begin{array}{l}46000 \\
(3)\end{array}$ & na & & $\begin{array}{l}16300 \\
(5)\end{array}$ & $\begin{array}{l}67500 \\
(4)\end{array}$ & $\begin{array}{l}22750 \\
(9)\end{array}$ \\
\hline $\begin{array}{l}\text { Kandungan } \\
\text { oksigen } \\
\text { (mg/L) }\end{array}$ & na & na & na & $\begin{array}{l}400 \\
(4)\end{array}$ & & $\begin{array}{l}21000 \\
(5)\end{array}$ & $\begin{array}{l}84000 \\
(4)\end{array}$ & na \\
\hline $\begin{array}{l}\text { Nitrogen/ N } \\
(\%)\end{array}$ & na & na & $\begin{array}{l}0,08 \\
(3)\end{array}$ & $\begin{array}{l}2,15 \\
3,25 \\
(2,4,11)\end{array}$ & - & $\begin{array}{l}0,07 \\
(5)\end{array}$ & $\begin{array}{l}1,74 \\
(4)\end{array}$ & $\begin{array}{l}0,15 \\
(9)\end{array}$ \\
\hline Fosfor/ P (\%) & $\begin{array}{l}0,8 \\
(14)\end{array}$ & na & $\begin{array}{l}0,2 \\
(3)\end{array}$ & $\begin{array}{l}0,03 \\
0,07 \\
(2,4,11)\end{array}$ & - & $\begin{array}{l}0,01 \\
(5)\end{array}$ & $\begin{array}{l}0,74 \\
(4)\end{array}$ & na \\
\hline Kalium/ K (\%) & $\begin{array}{l}1,49 \\
(12,14)\end{array}$ & na & na & $\begin{array}{l}4,82 \\
12,6 \\
(2,4,11)\end{array}$ & - & $\begin{array}{l}0,12 \\
(5)\end{array}$ & $\begin{array}{l}0,02 \\
(4)\end{array}$ & $\begin{array}{l}0,22 \\
(9)\end{array}$ \\
\hline $\begin{array}{l}\begin{array}{l}\text { Kalsium/ Ca } \\
\text { (ppm) }\end{array} \\
\end{array}$ & na & na & na & $\begin{array}{l}39 \\
(4)\end{array}$ & & $\begin{array}{l}12 \\
(5)\end{array}$ & $\begin{array}{l}240 \\
(4)\end{array}$ & na \\
\hline $\begin{array}{l}\text { Natrium/ } \mathrm{Na} \\
(\mathrm{ppm})\end{array}$ & $\begin{array}{l}1048 \\
(12)\end{array}$ & na & na & $\begin{array}{l}21000 \\
(4)\end{array}$ & & $\begin{array}{l}120 \\
(5)\end{array}$ & $\begin{array}{l}80 \\
(4)\end{array}$ & $\begin{array}{l}358,6 \\
(9)\end{array}$ \\
\hline $\begin{array}{ll}\begin{array}{l}\text { Besi/ } \\
(\mathrm{ppm})\end{array} & \mathrm{Fe} \\
\end{array}$ & na & na & $\begin{array}{l}317 \\
(3)\end{array}$ & 226 & & $\begin{array}{l}18 \\
(5)\end{array}$ & $\begin{array}{l}25 \\
(4)\end{array}$ & na \\
\hline $\begin{array}{l}\text { Mangan/ Mn } \\
(\mathrm{ppm})\end{array}$ & $\begin{array}{l}10,20 \\
(12)\end{array}$ & na & na & $\begin{array}{l}3,4 \\
(4)\end{array}$ & & na & na & na \\
\hline $\begin{array}{ll}\text { Zink/ } & \text { Zn } \\
(\mathrm{ppm})\end{array}$ & $\begin{array}{l}2,9 \\
(12)\end{array}$ & na & na & $\begin{array}{l}12 \\
(4)\end{array}$ & & $\begin{array}{l}12 \\
(5)\end{array}$ & $\begin{array}{l}21 \\
(4)\end{array}$ & na \\
\hline $\begin{array}{l}\text { Tembaga/ Cu } \\
\text { (ppm) }\end{array}$ & $\begin{array}{l}4,1 \\
(12)\end{array}$ & na & $\begin{array}{l}37 \\
(3)\end{array}$ & $\begin{array}{l}2,1 \\
(4)\end{array}$ & & $\begin{array}{l}0,05 \\
(5)\end{array}$ & $\begin{array}{l}1,2 \\
(4)\end{array}$ & na \\
\hline
\end{tabular}

na $=$ data tidak tersedia

Angka dalam tanda kurung merujuk pada nomor referensi yang digunakan berikut: 
1. (Garcia-Garcia et al. 1997) ; 2. (Gemtos et al. 1999); 3. (Wilkie et al. 2000); 4. (Vlyssides, et al. 2005); 5. (Tejada et al. 2007); 6. (Lutoslawski et al. 2011); 7. (Siles et al. 2011); 8. (Ahmed et al. 2013)); 9. (Aimaretti dan Ybalo 2012); 10.(Syaichurrozi et al. 2013); 11(Hernández et al 2019); 12. (Ortiz and Erazzú 2019); 13. (Velásquez-Riaño et.al 2019); 14. (Zali et al. 2019)

Vinase yang belum diolah (vinase mentah/ raw vinasse) kerap menjadi masalah bagi industri bioetanol karena volume yang dihasilkan sangat besar dan hal tersebut berkontribusi terhadap pencemaran lingkungan (Prado et al. 2013). Mulyanto (2018) menyatakan bahwa secara garis besar, terdapat dua opsi pemanfaatan utama vinase, yaitu sebagai pupuk cair dan sebagai sumber energi (biogas). Pemanfaatan vinase tebu yang belum diolah sebagai pupuk dalam pertanaman tebu, merupakan salah satu solusi penggunaan ulang dan pembuangan vinase (Christofoletti et al. 2013). Secara praktikal, aplikasi vinase ke lahan pertanian atau perkebunan dapat dilakukan dengan berbagai metode, seperti penyemprotan secara manual dengan nozzle, aplikasi melalui sprinkler, dan lain sebagainya. Vinase dapat diangkut dari pabrik bioetanol ke lahan tebu dengan dua cara, baik pengaliran vinase dari pabrik bioetanol ke lahan melalui pipa ataupun pengangkutan vinase dari pabrik bioetanol ke lahan dengan menggunakan truk. Pada lahan yang tebu dengan luasan kecil dan jarak dengan pabrik bioetanol tidak begitu jauh, vinase dapat dialirkan melalui pipa, sedangkan pengangkutan vinase dengan menggunakan truk lebih cocok diterapkan pada lahan tebu dengan luasan besar dan jarak dengan pabrik bioetanol jauh (Gemtos et al. 1999).Guna mempermudah aplikasi vinase di lapangan dalam jumlah yang besar maka dibutuhkan teknik fertigasi.

Fertigasi merupakan kegiatan pemberian hara tanaman yang dilaksanakan secara bersamaan dengan irigasi (Kafkafi and Tarchitzky 2011; Liu et al. 2019). Pada proses fertigasi, zat hara, seperti nitrogen, fosfor, kalium, dan karbon, ditambahkan ke dalam air irigasi pertanian, yang bertujuan untuk meningkatkan pertumbuhan tanaman. Libardi et al. (2019) menemukan bahwa fertigasi meningkatkan produktivitas tanaman tebu keprasan kedua dan ketiga sebesar masing-masing $43,5 \%$ dan $67,2 \%$. Walaupun demikian, fertigasi juga termasuk praktik penggunaan air limbah industri dan domestik, termasuk vinase. Air limbah seperti vinase mengandung nutrien dalam jumlah yang besar sehingga berpotensi untuk meningkatkan pertumbuhan tanaman. Fertigasi dengan air limbah juga memberikan berbagai manfaat lain, seperti menghemat penggunaan air bersih, mengurangi ketergantungan terhadap penggunaan pupuk mineral, dan membantu mengurangi jumlah air limbah (Chauhan and Kumar 2017). Fertigasi dengan memanfaatkan vinase sebagai bahan pemupukan pada perkebunan tebu merupakan salah satu alternatif terbaik dalam penanganan limbah ini (Christofoletti et al. 2013). Penggunaan vinase pada fertigasi merupakan alternatif pemupukan lahan pertanian sekaligus mencegah pembuangan vinase pada lingkungan terbuka. Fertigasi vinase ke perkebunan tebu sebagai pupuk cair dapat membawa manfaat bagi kesuburan tanah dan perbaikan sifat fisik tanah mengingat degradasi lahan sering terjadi pada lahan perkebunan tebu, terutama pada lahan tebu yang menerapkan sistem monokultur selama bertahun-tahun (Putra et al. 2020). Metode fertigasi memberikan berbagai keuntungan lain, yaitu membutuhkan investasi awal yang rendah untuk pembelian alat (pompa, pipa, truk, dan tanki), biaya perawatan 
alat yang rendah, tidak memerlukan teknologi kompleks, dan aplikasi dapat dilakukan dengan cepat (Santana and Fernandes Machado 2008).

Bagi sebagian pihak, aplikasi vinase sebagai bahan fertigasi ke perkebunan tebu diharapkan dapat menjadi upaya penerapan pertanian sirkuler, yaitu pemanfaatan kembali sisa limbah atau residu pertanian ke dalam sistem pertanian sebagai sumberdaya yang dapat diperbarui. Namun, hal tersebut tidak jarang menimbulkan kontra bagi sebagian pihak lainnya karena adanya dampak negatif aplikasi vinase terhadap lingkungan. Tulisan ini bertujuan untuk meninjau potensi pemanfaatan vinase sebagai sumber bahan fertigasi pada perkebunan tebu.

\section{Metodologi}

Metode yang digunakan adalah kajian literatur dari berbagai jurnal ilmiah yang terkait dengan vinase dan aplikasinya dalam fertigasi.

\section{Pembahasan}

\subsection{Potensi Vinase sebagai Bahan Fertigasi Dan Bahan Pembenah Tanah}

Vinase pada umumnya merupakan produk sampingan yang dibuang ke tanah (Moran-Salazar et al. 2016) atau ke badan air (Cabrera-Díaz et al. 2016). Aplikasi vinase ke tanah merupakan praktik yang umum diterapkan di areal perkebunan tebu (Cavalett et al. 2012; Ortegón et al. 2016; Ortiz and Erazzú 2019; Pita et al. 2009). Vinase diaplikasikan melalui irigasi ke lapang (fertigasi) sebagai pupuk yang sederhana dan murah serta mengurangi kebutuhan masukan (input) bahan kimia. Di negara dengan luas perkebunan tanaman tebu terbesar di dunia yaitu Brazil, fertigasi vinase ke perkebunan tebu merupakan hal yang lazim dilakukan (Fuess and Garcia 2015). Di lapang, volume vinase yang dapat diaplikasikan berada pada kisaran 60.000 hingga 300.000 liter per hektar tergantung dari konsentrasi vinase yang digunakan (Olivera-Guerra et al. 2018). Vinase juga mengandung bahan organik yang dapat dimanfaatkan.

Bahan organik yang berasal dari limbah pertanian dan industri pada umumnya mengandung bahan organik dan nutrien dalam jumlah tinggi, sehingga dapat dimanfaatkan sebagai pupuk tanaman atau bahan pembenah tanah, baik diberikan secara langsung atau melalui proses pengolahan terlebih dahulu (Gallardo-Lara and Perez 1990). Vinase dapat digunakan sebagai pupuk untuk tanaman tebu karena memiliki kandungan bahan organik dan kalium yang tinggi (Bonomi et al. 2016; Cassman et al. 2018; Prado et al. 2013; Valdés-Gómez et al. 2009), serta mengandung nitrogen, fosfor, dan nutrien lain dalam jumlah sedang atau moderat. De Resende et al. (2006) menemukan bahwa vinase mengandung nitrogen, fosfor, kalsium, dan magnesium yang masing-masingnya berjumlah 0,28 , $0,33,0,10$ dan $0,13 \mathrm{~kg} / \mathrm{m} 3$. Proses humifikasi dan mineralisasi pada vinase yang diaplikasikan ke tanah dapat berkontribusi positif terhadap perubahan sifat kimia dan fisik tanah, sehingga mendukung pertumbuhan tanaman. Kesuburan tanah akan meningkat karena adanya peningkatan bahan organik dan nutrien dari vinase ke dalam tanah (Cabrera-Díaz et al. 2016). Selain meningkatkan ketersediaan nutrien tanah, vinase juga dapat meningkatkan kadar air tanah (Seddik, Osman, dan Kenawy 2016) karena vinase memiliki kadar air yang tinggi. Ahmed O., Moneim Sulieman dan Elhardallou (2013) melaporkan bahwa vinase mengandung kadar air sebesar $82,27 \%$, sedangkan sisanya terdiri dari abu (10,6\%), protein $(6,2 \%)$, serta sedikit kandungan karbohidrat $(0,93 \%)$. 
Vinase memiliki potensi untuk mensubstitusikan pupuk kimia pada perkebunan tebu karena berbagai dampak positif yang ditimbulkannya terhadap sifat kimia dan biologi tanah, serta hasil tebu (Yang et al. 2013). Abiy Fantaye (2014) menyebut bahwa vinase dapat diaplikasikan ke perkebunan tebu sebagai bahan substitusi pupuk kalium konvensional. Bonomi et al. (2016) menemukan bahwa kandungan kalium dalam vinase dapat menggantikan $100 \%$ kalium dari pupuk mineral pada tanaman tebu ratun. Olivera-Guerra et al. (2018) menyebut bahwa vinase dapat menggantikan pupuk kalium. Vinase dapat menggantikan pupuk kalium secara penuh dan pupuk fosfor secara sebagian. Sadewo (2017) menemukan bahwa penggunaan vinase cair dengan dosis sebanyak 12.000 liter per hektar mampu digunakan sebagai bahan substitusi pupuk kalium sebesar $100 \%$ (setara dengan $200 \mathrm{~kg} \mathrm{KCl}$ per hektar). Namun, perlu diperhatikan bahwa konsentrasi kalium dalam vinase yang dihasilkan dari molases lebih tinggi dibandingkan dari sumber lain seperti nira tebu. Fakta bahwa vinase dapat menggantikan pupuk kalium pada budidaya tanaman tebu sangat menarik secara ekonomis. Hal ini disebabkan karena pemupukan kalium dalam budidaya tanaman tebu umumnya menggunakan pupuk $\mathrm{KCl}$ yang tidak murah (Alcoforado de Moraes et al. 2010).

Beberapa penelitian menunjukkan bahwa aplikasi vinase meningkatkan kandungan bahan organik tanah (Rosabal et al. 2007; Seddik et al. 2016), kandungan nitrogen total tanah (Gemtos et al. 1999; Jiang et al. 2012; Seddik et al. 2016), dan kandungan kalium tanah (Gemtos et al. 1999; Jiang et al. 2012; Rotunno Filho et al. 2014; Sanchez-Lizarraga et al. 2018; Seddik et al. 2016; Soobadar and $\mathrm{Ng}$ Kee Kwong 2012). Peningkatan unsur nitrogen oleh aplikasi vinase umumnya tidak signifikan dan belum dapat menggantikan pupuk nitrogen sintetis. De Moraes et al. (2009) menyebut bahwa vinase dapat menggantikan pupuk kalium dan sulfur secara total dalam budidaya tebu, namun hanya bisa menggantikan nitrogen secara parsial. Kandungan nitrogen dalam vinase hanya dapat menggantikan $20 \%$ nitrogen dari pupuk mineral pada tanaman tebu ratun (Bonomi et al. 2016). Dengan demikian, tambahan pupuk nitrogen pada budidaya tanaman tebu tetap diperlukan meskipun vinase diaplikasikan ke tanah sebagai fertigasi (Pita et al. 2009).

Beberapa studi menunjukkan bahwa aplikasi vinase meningkatkan simpanan karbon di tanah (Jiang et al. 2012; Soobadar and Ng Kee Kwong 2012; Zani et al. 2018). Zani et al. (2018) menemukan bahwa aplikasi vinase menyebabkan akumulasi karbon tanah sebesar $0,55 \mathrm{Mg}$ per hektar per tahun pada kedalaman 0$30 \mathrm{~cm}$. Vinase merupakan sumber karbon terlarut (Christofoletti et al. 2013). Aplikasi vinase mempertahankan dan memulihkan tanah dari efek pembakaran tebu, dimana kondisi kandungan karbon organik tanah, karbon organik partikulat, karbon organik berasosiasi mineral, asam humat, humin dan kandungan oganik fraksi ringan yang terkena kebakaran mengalami peningkatan dan kandungan senyawa-senyawa tersebut pun mengalami pemulihan.

Berkaitan dengan sifat fisik tanah aplikasi vinase bersamaan dengan bahan organik meningkatkan sifat fisik tanah dan mobilisasi nutrien. Jiang et al. (2012) melaporkan bahwa aplikasi vinase meningkatkan total porositas dan porositas kapiler di lapisan bajak tanah dan meningkatkan persentase agregat tanah besar yang stabil terhadap air secara signifikan. Mereka menduga hal tersebut berkaitan dengan ketersediaan kelembaban tanah dan meningkatnya kandungan bahan 
organik tanah akibat pemberian vinase. Vinase juga dapat meningkatkan kandungan air tanah (Seddik et al. 2016) dalam jangka waktu tertentu mengingat konstituen terbesar vinase sekitar 90\% adalah air (Vyatrisa, Muhartini, dan Waluyo 2017) Dalam sebuah percobaan lapang, Stepkowska et al. (2001) menemukan bahwa aplikasi vinase ke tanah pasiran dan lempung meningkatkan retensi air tanah pada $\mathrm{p} / \mathrm{p} 0=1$. Dengan demikian, aplikasi vinase baik diterapkan pada lahan tebu kering dengan curah hujan tahunan yang rendah. Kecukupan air pada budidaya tebu penting karena tanaman tebu dapat kehilangan hasil hingga $40 \%$ bila mengalami kekeringan terutama pada fase kritis tanaman. Walaupun beberapa peneliti mengungkapkan bahwa vinase membawa dampak positif terhadap sifat fisik tanah, beberapa tidak menemukan dampak positif aplikasi vinase terhadap porositas total, makroporositas, dan mikroporositas tanah latosol pada perkebunan tebu. la menduga tidak adanya dampak positif vinase terhadap sifat fisik tanah disebabkan karena kurangnya bahan organik dalam tanah tersebut.

Beberapa dampak positif aplikasi vinase terhadap sifat biologi tanah, antara lain meningkatkan populasi fungi (Lourenço et al. 2020), meningkatkan keragaman jenis bakteri di tanah dan mempromosikan beberapa spesies bakteri tanah yang berpartisipasi dalam siklus nitrogen dan besi (Omori et al. 2016) serta meningkatkan populasi actinomycetes tanah (Yang et al. 2013). Peningkatan populasi mikroba pada tanah yang diberi vinase (terutama fungi), antara lain Neurospora ssp, Aspergillus ssp, Penicillum ssp, Mucor ssp, dan Streptomyces ssp. Kandungan bahan organik pada vinase merupakan sumber karbon terlarut (gliserol) penting dan tersedia bagi mikroorganisme (Prata et al. 2001). Vinase mengandung nutrisi yang dapat menstimulasi aktivitas mikroorganisme (Christofoletti et al. 2013). Aplikasi vinase juga diketahui meningkatkan laju mineralisasi nitrogen oleh aktivitas mikroba (Yang et al. 2013). Secara umum, keberadaan mikroorganisme tanah seperti fungi dan bakteri sangat penting karena mikroorganisme tersebut berperan mendekomposisi material organik menjadi nutrien tanah yang tersedia bagi tanaman.

Tabel 2. Dampak positif aplikasi vinase ke lahan tebu yang dilaporkan oleh berbagai studi di berbagai negara

\begin{tabular}{|c|c|c|}
\hline \multicolumn{2}{|c|}{$\begin{array}{c}\text { Dampak positif aplikasi vinase ke } \\
\text { lahan tebu }\end{array}$} & \multirow[t]{2}{*}{ Referensi } \\
\hline Parameter & Dampak positif & \\
\hline \multirow[t]{3}{*}{$\begin{array}{l}\text { Sifat fisik } \\
\text { tanah }\end{array}$} & $\begin{array}{l}\text { Meningkatkan total } \\
\text { porositas dan } \\
\text { porositas kapiler di } \\
\text { lapisan bajak } \\
\text { tanah }\end{array}$ & $\begin{array}{l}\text { - (Jiang et al. 2012) Changping, Fusui, } \\
\text { Guangxi, China }\end{array}$ \\
\hline & $\begin{array}{l}\text { Meningkatkan } \\
\text { persentase } \\
\text { agregat tanah } \\
\text { besar yang stabil } \\
\text { terhadap air }\end{array}$ & $\begin{array}{l}\text { - (Jiang et al. 2012) Changping, Fusui, } \\
\text { Guangxi, China }\end{array}$ \\
\hline & $\begin{array}{l}\text { Meningkatkan } \\
\text { retensi/kadar air } \\
\text { tanah }\end{array}$ & $\begin{array}{l}\text { - (Stepkowska et al. 2001) } \\
\text { - (Seddik et al. 2016) smailia, Mesir }\end{array}$ \\
\hline $\begin{array}{l}\text { Sifat kimia } \\
\text { tanah }\end{array}$ & $\begin{array}{l}\text { Meningkatkan } \\
\text { kandungan bahan }\end{array}$ & $\begin{array}{l}\text { - (Rosabal et al. 2007) La Habana, Kuba } \\
\text { - (Seddik et al. 2016) Ismailia, Mesir }\end{array}$ \\
\hline
\end{tabular}




\begin{tabular}{|c|c|c|}
\hline \multicolumn{2}{|c|}{$\begin{array}{c}\text { Dampak positif aplikasi vinase ke } \\
\text { lahan tebu }\end{array}$} & \multirow[t]{2}{*}{ Referensi } \\
\hline Parameter & Dampak positif & \\
\hline & organik tanah & \\
\hline & $\begin{array}{l}\text { Meningkatkan } \\
\text { kandungan } \\
\text { nitrogen tanah }\end{array}$ & $\begin{array}{l}\text { - (Gemtos et al. 1999) Yunani Tengah } \\
\text { - (Yang et al. 2013) Qianjiang, Guangxi, China } \\
\text { - (Seddik et al. 2016) Ismailia, Mesir }\end{array}$ \\
\hline & $\begin{array}{l}\text { Meningkatkan } \\
\text { kandungan kalium } \\
\text { tanah }\end{array}$ & $\begin{array}{l}\text { - (Gemtos et al. 1999) Yunani Tengah } \\
\text { - (Jiang et al. 2012) Changping, Fusui, } \\
\text { Guangxi, China } \\
\text { - (Soobadar and Ng Kee Kwong 2012) } \\
\text { Mauritius } \\
\text { - (Seddik et al. 2016) Ismailia, Mesir } \\
\text { - (Oliveira Filho et al. 2021) Brazil Tenggara } \\
\text {-(Sanchez-Lizarraga et al. 2018) Meksiko }\end{array}$ \\
\hline & $\begin{array}{l}\text { Meningkatkan } \\
\text { kandungan fosfor } \\
\text { tanah }\end{array}$ & $\begin{array}{l}\text { - (Seddik et al. 2016) Ismailia, Mesir } \\
\text { - (Oliveira Filho et al. 2021) Brazil Tenggara } \\
\text {-(Sanchez-Lizarraga et al. 2018) Meksiko }\end{array}$ \\
\hline & $\begin{array}{l}\text { Terakumulasi } \\
\text { sebagai karbon } \\
\text { tanah }\end{array}$ & $\begin{array}{l}\text { - (Soobadar and Ng Kee Kwong 2012) } \\
\text { Mauritius } \\
\text {-(Yang et al. 2013) Qianjiang, Guangxi, China }\end{array}$ \\
\hline \multirow[t]{3}{*}{$\begin{array}{l}\text { Sifat biologi } \\
\text { tanah }\end{array}$} & $\begin{array}{l}\text { Meningkatkan } \\
\text { populasi fungi } \\
\text { tanah }\end{array}$ & $\begin{array}{l}\text { - (Lourenço et al. 2020) Piracicaba, Brazil } \\
\text { - (Yang et al. 2013) Qianjiang, Guangxi, China }\end{array}$ \\
\hline & $\begin{array}{l}\text { Meningkatkan } \\
\text { populasi bakteri } \\
\text { tanah }\end{array}$ & $\begin{array}{l}\text { - (Omori et al. 2016) Nova Europa, São Paulo, } \\
\text { Brazil } \\
\text {-(Yang et al. 2013) Qianjiang, Guangxi, China }\end{array}$ \\
\hline & $\begin{array}{l}\text { Meningkatkan } \\
\text { populasi } \\
\text { actinomycetes } \\
\text { tanah }\end{array}$ & - (Yang et al. 2013) Qianjiang, Guangxi, China \\
\hline $\begin{array}{l}\text { Pertumbuhan } \\
\text { tanaman } \\
\text { tebu }\end{array}$ & $\begin{array}{l}\text { Meningkatkan hasil } \\
\text { dan produktivitas } \\
\text { tanaman tebu }\end{array}$ & $\begin{array}{l}\text { - (Rodriguez 2000) Lara, Venezuela } \\
\text { - (Rosabal et al. 2007) La Habana, Kuba } \\
\text { - (Jiang et al. 2012) Changping, Fusui, } \\
\text { Guangxi, China } \\
\text { - (Yang et al. 2013) Qianjiang, Guangxi, China }\end{array}$ \\
\hline
\end{tabular}

Aplikasi vinase dalam jangka waktu moderat ke dalam lahan pertanaman tebu memicu lingkungan tanah yang baik untuk pertumbuhan tanaman tebu (Jiang et al. 2012; Rodriguez 2000). Beberapa penelitian sebelumnya menemukan bahwa aplikasi vinase meningkatkan hasil tebu dan gula (Jiang et al. 2012; Prado et al. 2013; Rodriguez 2000; Yang et al. 2013). Berdasarkan penelitian lapang di Kediri dan Mojokerto, Jawa Timur, aplikasi vinase yang diperkaya mikroba (berbentuk pupuk hayati cair) menunjukkan hasil positif terhadap pertumbuhan tebu. Perlakuan pupuk hayati cair berbasis vinase sebanyak 50 ribu liter per hektar dan pupuk anorganik $100 \%$ memberikan hasil jumlah batang per juring 108 dan tinggi batang $278 \mathrm{~cm}$ dibandingkan bila hanya menggunakan pupuk organik dimana jumlah batang per juring sebesar 76 dan tinggi batang $249 \mathrm{~cm}$. Hasil tebu yang lebih tinggi dengan aplikasi vinase berkaitan dengan ketersediaan kalium dan nitrogen total (Prado et al., 2013; Wei et al. 2014) serta mikronutrien yang tinggi (Yang et al. 2013). Dalam sebuah penelitian selama tiga tahun yang meliputi 
tanaman baru (plant cane) dan ratun, aplikasi vinase yang dikombinasikan bersama pupuk mineral terbukti memberikan hasil tebu yang lebih tinggi dibandingkan pupuk mineral sendiri (Soobadar dan Ng Kee Kwong 2012).

\subsection{Potensi Vinasi sebagai Bahan Pencemar Lingkungan}

Pada saat ini masih ada pabrik bioetanol yang langsung membuang vinase mentah yang belum terolah) ke lingkungan terbuka, termasuk lahan pertanian tanpa terlebih dahulu memproses limbah tersebut. Padahal, aplikasi tersebut dapat memberikan dampak negatif yaitu mencemari lingkungan. Aplikasi vinase ke lahan tebu memang dapat membawa dampak positif terhadap karakteristik dan status nutrien tanah yang pada akhirnya akan meningkatkan pertumbuhan tanaman tebu. Namun, aplikasi vinase secara langsung secara terus menerus dalam jangka waktu panjang ke tanah dan badan air dapat menyebabkan permasalahan lingkungan serius (Dabral et al., 2016; Fuess dan Garcia 2015). Hal ini terjadi bila vinase yang digunakan yaitu vinase mentah atau tidak diolah terlebih dahulu sebelum digunakan sebagai bahan fertigasi.

Vinase mentah dapat membuat tanah menjadi jenuh akan bahan organik dan mengkontaminasi badan air, terlebih bila dalam skala (España-Gamboa et al. 2011). Dalam jangka waktu lama, vinase mentah dapat memicu terjadinya kejenuhan tanah dengan fosfor inorganik, garam, ion-ion, dan beberapa komponen kimia lainnya (Moran-Salazar et al. 2016). Vinase mentah juga akan membanjiri pori-pori tanah sehingga mengurangi aerasi tanah. Jumlah bahan organik berlebih pada vinase mentah juga menjadi hal yang menyebabkan penyumbatan pori tanah.

\section{Kesimpulan}

Aplikasi vinase mentah pada lahan perkebunan tebu dapat memberikan dampak positif, namun juga membawa dampak negatif terhadap sifat fisika, kimia, dan biologi tanah, serta pertumbuhan tebu. Dampak positif vinase terhadap lingkungan dan pertanian terutama karena mengandung nutrien seperti kalium, nitrogen, serta beberapa mikronutrien yang dibutuhkan untuk pertumbuhan dan perkembangan tanaman tebu. Dampak negatif terjadi apabila vinase diaplikasikan tanpa diolah dan dalam jangka waktu yang terus menerus.

\section{Daftar Pustaka}

Abiy Fantaye, Ambachew Dametie. 2014. "Estimating Effect of Vinasse on Sugarcane through Application of Potassium Chloride at Metahara Sugarcane Plantation." Advances in Crop Science and Technology 02(05):2-5. doi: 10.4172/2329-8863.1000154.

Adhitya, Fazriyan Wardani, Djoni Hartono, and Agni Alam Awirya. 2013. "Determinan Produktivitas Lahan Pertanian Subsektor Tanaman Pangan Di Indonesia." Jurnal Ekonomi Pembangunan.

Ahmed O., Moneim Sulieman, Abdel E., and Sirelkhatim B. Elhardallou. 2013. "Physicochemical, Chemical and Microbiological Characteristics of Vinasse, A By-Product from Ethanol Industry." American Journal of Biochemistry 2013(3):80-83. doi: 10.5923/j.ajb.20130303.03.

Aimaretti, N., and C. Ybalo. 2012. "Valorization of Carrot and Yeast Discards for the Obtention of Ethanol." Biomass and Bioenergy, 42: 18-23. 
Alcoforado de Moraes, Márcia Maria Guedes, Ximing Cai, Claudia Ringler, Bruno Edson Albuquerque, Sérgio P. Vieira da Rocha, and Carlos Alberto Amorim. 2010. "Joint Water Quantity-Quality Management in a Biofuel Production Area-Integrated Economic-Hydrologic Modeling Analysis." Journal of Water Resources Planning and Management 136(4):502-11. doi: 10.1061/(asce)wr.1943-5452.0000049.

Aprinada, Carrin, Irvan S. Kartawiria, and Evita H. Legowo. 2019. "Net Energy Analysis of Molasses Based Bioethanol Production in Indonesia." Iconiet Proceeding 2(1):25-30. doi: 10.33555/iconiet.v2i1.6.

Bonomi, Antonio, Otávio Cavalett, Marcelo Pereira da Cunha, and M. A. Lima. 2016. Virtual Biorefinery - An Optimization Strategy for Renewable Carbon Valorization. Springer International Publishing.

Cabrera-Díaz, A., I. Pereda-Reyes, J. Dueñas-Moreno, E. Véliz-Lorenzo, M. A. Díaz-Marrero, C. L. Menéndez-Gutiérrez, D. Oliva-Merencio, and M. Zaiat. 2016. "Combined Treatment of Vinasse by an Upflow Anaerobic FilterReactor and Ozonation Process." Brazilian Journal of Chemical Engineering 33(4):753-62. doi: 10.1590/0104-6632.20160334s20150268.

Cassman, Noriko A., Késia S. Lourenço, Janaína B. Do Carmo, Heitor Cantarella, and Eiko E. Kuramae. 2018. "Genome-Resolved Metagenomics of Sugarcane Vinasse Bacteria." Biotechnology for Biofuels 11(1):1-16. doi: 10.1186/s13068-018-1036-9.

Cavalett, Otávio, Tassia L. Junqueira, Marina O. S. Dias, Charles D. F. Jesus, Paulo E. Mantelatto, Marcelo P. Cunha, Henrique C. J. Franco, Terezinha F. Cardoso, Rubens Maciel Filho, Carlos E. V. Rossell, and Antonio Bonomi. 2012. "Environmental and Economic Assessment of Sugarcane First Generation Biorefineries in Brazil." Clean Technologies and Environmental Policy 14(3):399-410. doi: 10.1007/s10098-011-0424-7.

Chauhan, Prashant Singh, and Anil Kumar. 2017. "Heat Transfer Analysis of North Wall Insulated Greenhouse Dryer under Natural Convection Mode." Energy 118:1264-74. doi: 10.1016/j.energy.2016.11.006.

Christofoletti, Cintya Aparecida, Janaína Pedro Escher, Jorge Evangelista Correia, Julia Fernanda Urbano Marinho, and Carmem Silvia Fontanetti. 2013. "Sugarcane Vinasse: Environmental Implications of Its Use." Waste Management 33(12):2752-61. doi: 10.1016/j.wasman.2013.09.005.

Dabral, Parmendra Prasad, Amardeep Kumar, and Gymar Tana. 2016. "Determination of Surface Drainage Coefficient - A Case Study of Doimukh (Arunachal Pradesh), India." Agricultural Engineering International: CIGR Journal 18(4):1-10.

España-Gamboa, Elda, Javier Mijangos-Cortes, Luis Barahona-Perez, Jorge Dominguez-Maldonado, G. Hernández-Zarate, and Liliana Alzate-Gaviria. 2011. "Vinasses: Characterization and Treatments." Waste Management and Research 29(12):1235-50. doi: 10.1177/0734242X10387313.

Fuess, Lucas Tadeu, and Marcelo Loureiro Garcia. 2015. "Bioenergy from Stillage Anaerobic Digestion to Enhance the Energy Balance Ratio of Ethanol Production." Journal of Environmental Management 162:102-14. doi: 10.1016/j.jenvman.2015.07.046. 
Gallardo-Lara, F., and J. D. Perez. 1990. "Direct, Delayed and Residual Effects of Applied Wastewater from Olive Processing on Nitrogen and Phosphorus Availability in the Soil-Plant System." Journal of Environmental Science and Health, Part B 25(3):379-94. doi: 10.1080/03601239009372696.

Garcia-Garcia, I., J. L. Bonilla-Venceslada, P. R. Jimenez-Pena, and E. RamosGomez. 1997. "Biodegradation of Phenol Compounds in Vinasse Using Aspergillusterreus and Geotrichumcandidum." Water Research 31(8):200511.

Gemtos, T. A., N. Chouliaras, and St Marakis. 1999. "Vinasse Rate, Time of Application and Compaction Effect on Soil Properties and Durum Wheat Crop." Journal of Agricultural Engineering Research 73(3):283-96. doi: 10.1006/jaer.1999.0419.

Gurgel, Marcílio N. d. A., Simone T. R. Correa, Durval Dourado Neto, and Durval R. De Paula Júnior. 2015. "Technology for Sugarcane Agroindustry Waste Reuse as Granulated Organomineral Fertilizer." Engenharia Agricola 35(1):63-75. doi: 10.1590/1809-4430-Eng.Agric.v35n1p63-75/2015.

Hannon, K., and A. Trenkle. 1990. "Evaluation of Condensed Molasses Fermentation Solubles as a Nonprotein Nitrogen Source for Ruminants." Jurnal Animal Science 68:2634-41.

Hernández, J., Viana, M. T., Lastra, M., Matus de la Parra, A., and Toledo-Agüero, P. 2019. "The Possible Use of Beet-Vinasse as Carbohydrate Replacer in Formulated Diets for the Juvenile Abalone, Haliotis Tuberculata." Journal of Applied Aquaculture 31(3):271-88.

Jeon, Bo Young, Soo Jin Kim, Dae Hee Kim, Byung Kwan Na, Doo Hyun Park, Hung Thuan Tran, Ruihong Zhang, and Dae Hee Ahn. 2007. "Development of a Serial Bioreactor System for Direct Ethanol Production from Starch Using Aspergillus Niger and Saccharomyces Cerevisiae." Biotechnology and Bioprocess Engineering 12(5):566-73. doi: 10.1007/BF02931356.

Jiang, Ze Pu, Yang Rui Li, Guang Po Wei, Qing Liao, Tian Ming Su, Yan Cheng Meng, Hai Ying Zhang, and Chang Yan Lu. 2012. "Effect of Long-Term Vinasse Application on Physico-Chemical Properties of Sugarcane Field Soils." Sugar Tech 14(4):412-17. doi: 10.1007/s12355-012-0174-9.

Jiménez, A. M., R. Borja, A. Martín, and F. Raposo. 2006. "Kinetic Analysis of the Anaerobic Digestion of Untreated Vinasses and Vinasses Previously Treated with Penicillium Decumbens." Journal of Environmental Management 80(4):303-10. doi: 10.1016/j.jenvman.2005.09.011.

Kafkafi, U., and J. Tarchitzky. 2011. Fertigation A Tool for Efficient Fertilizer and Water Management.

Khatiwada, Dilip, and Semida Silveira. 2017. "Scenarios for Bioethanol Production in Indonesia: How Can We Meet Mandatory Blending Targets?" Energy 119:351-61. doi: 10.1016/j.energy.2016.12.073.

Li, Jiang, Ting Zhu, Xiaomin Mao, and Adebayo J. Adeloye. 2016. "Modeling Crop Water Consumption and Water Productivity in the Middle Reaches of Heihe River Basin." Computers and Electronics in Agriculture 123:242-55. doi: 10.1016/j.compag.2016.02.021. 
Libardi, Luís Guilherme Polizel, Rogério Teixeira de Faria, Alexandre Barcellos Dalri, Glauco de Souza Rolim, Luiz Fabiano Palaretti, Anderson Prates Coelho, and Izabela Paiva Martins. 2019. "Evapotranspiration and Crop Coefficient (Kc) of Pre-Sprouted Sugarcane Plantlets for Greenhouse Irrigation Management." Agricultural Water Management 212(April 2018):306-16. doi: 10.1016/j.agwat.2018.09.003.

Liu, Yuan, Erping Cui, Andrew L. Neal, Xiaoxian Zhang, Zhongyang Li, Yatao Xiao, Zhenjie Du, Feng Gao, Xiangyang Fan, and Chao Hu. 2019. "Reducing Water Use by Alternate-Furrow Irrigation with Livestock Wastewater Reduces Antibiotic Resistance Gene Abundance in the Rhizosphere but Not in the Non-Rhizosphere." Science of the Total Environment 648:12-24. doi: 10.1016/j.scitotenv.2018.08.101.

Lourenço, Késia Silva, Afnan Khalil Ahmad Suleiman, Agata Pijl, Heitor Cantarella, and Eiko Eurya Kuramae. 2020. "Dynamics and Resilience of Soil Mycobiome under Multiple Organic and Inorganic Pulse Disturbances." Science of the Total Environment 733:139173. doi: 10.1016/j.scitotenv.2020.139173.

Lutoslawski, K., A. Ryznar-Luty, E. Cibis, M. Krzywonos, and T. Miskiewicz. 2011. "Biodegradation of Beet Molasses Vinasse by a Mixed Culture of Microorganisms: Effect of Aeration Conditions and PH Control." Journal of Environmental Sciences 23(11):1823-30.

Martinelli, L. A., and S. Filloso. 2008. "NoExpansion of Sugarcane Ethanol Production in Brazil: Environmental and Social Challenges." Ecological Applications 18(4):885-98.

de Moraes, MMGA, CX Cai, B. E. Ringler, SP V Albuquerque, Da Rocha, and CA. Amorim. 2009. "Joint Water Quantity-Quality Management in a Biofuel Production Area-Integrated Economic-Hydrologic Modeling Analysis." Journal of Water Resources Planning and Management 136(4):502-11.

Moran-Salazar, R. G., A. L. Sanchez-Lizarraga, J. Rodriguez-Campos, G. DavilaVazquez, E. N. Marino-Marmolejo, L. Dendooven, and S. M. ContrerasRamos. 2016. "Utilization of Vinasses as Soil Amendment: Consequences and Perspectives." SpringerPlus 5(1). doi: 10.1186/s40064-016-2410-3.

Mulyanto, Adi. 2018. "Air Limbah Industri Bioetanol Berbahan Baku Ubi Kayu Sebagai Bahan Baku Produksi Biogas." Jurnal Rekayasa Lingkungan 6(3). doi: 10.29122/jrl.v6i3.1940.

Naik, Nagaraj M., K. S. Jagadeesh, and A. R. Alagawadi. 2008. "Microbial Decolorization of Spentwash: A Review." Indian Journal of Microbiology 48(1):41-48. doi: 10.1007/s12088-008-0005-6.

Nasution, Mutiara Naimi, Feliatra Feliatra, and Irwan Effendi. 2021. "ANALISIS PERTUMBUHAN PROTEIN SEL TUNGGAL (PST) BAKTERI Bacillus Cereus DENGAN MEDIA YANG BERBEDA." Jurnal Perikanan Dan Kelautan 26(1):47. doi: 10.31258/jpk.26.1.47-53.

Oliveira Filho, José de Souza, Otavio Augusto Queiroz dos Santos, Celeste Queiroz Rossi, Yan Vidal de Figueiredo Gomes Diniz, Hugo de Souza Fagundes, Luiz Alberto da Silva Rodrigues Pinto, Willian Pereira, and Marcos Gervasio Pereira. 2021. "Assessing the Effects of Harvesting with and without Burning and Vinasse Application in Sugarcane Crops: Evaluation of Soil 
Fertility and Phosphorus Pools in Different Ethanol Production Systems." Agriculture, Ecosystems and Environment 307(April 2020). doi: 10.1016/j.agee.2020.107233.

Olivera-Guerra, Luis, Olivier Merlin, Salah Er-Raki, Saïd Khabba, and Maria Jose Escorihuela. 2018. "Estimating the Water Budget Components of Irrigated Crops: Combining the FAO-56 Dual Crop Coefficient with Surface Temperature and Vegetation Index Data." Agricultural Water Management 208:120-31. doi: 10.1016/j.agwat.2018.06.014.

Omori, Wellington Pine, André Ferreira De Camargo, Karla Cristina Stropa Goulart, Eliana Gertrudes De Macedo Lemos, and Jackson Antônio Marcondes De Souza. 2016. "Influence of Vinasse Application in the Structure and Composition of the Bacterial Community of the Soil under Sugarcane Cultivation." International Journal of Microbiology 2016. doi: 10.1155/2016/2349514.

Ortegón, Gloria Páez, Fernando Muñoz Arboleda, Lucila Candela, Karim Tamoh, and Javier Valdes-Abellan. 2016. "Vinasse Application to Sugar Cane Fields. Effect on the Unsaturated Zone and Groundwater at Valle Del Cauca (Colombia)." Science of the Total Environment 539:410-19. doi: 10.1016/j.scitotenv.2015.08.153.

Ortiz, Joaquín Mario, and Luis Erazzú. 2019. "Sugarcane Energy: Potential Electricity Production from Vinasse Produced by the Ethanol Industry." Proceedings of the International Society of Sugar Cane Technologists 30(2006):1595-1602.

Pita, V., E. Vasconcelos, D. Fangueiro, F. Cabral, and H. M. Ribeiro. 2009. "Carbon and Nitrogen Mineralization of Organic Wastes From Sugarcane Distilleries : Vinasse and Yeast Waste." America 2-5.

Prado, Renato De Mello, Gustavo Caione, and Cid Naudi Silva Campos. 2013. "Filter Cake and Vinasse as Fertilizers Contributing to Conservation Agriculture." Applied and Environmental Soil Science 2013(Table 1). doi: 10.1155/2013/581984.

Prata, Fábio, Arquimedes Lavorenti, Jussara Borges Regitano, and Valdemar Luís Tornisielo. 2001. "Degradação e Sorção de Ametrina Em Dois Solos Com Aplicação de Vinhaça." Pesq. Agropec. Bras. 36(7):975-81.

Putra, R. P., M. R. R. Ranomahera, M. S. Rizaludin, R. Supriyanto, and V. A. K. Dewi. 2020. "Investigating Environmental Impacts of Long-Term Monoculture of Sugarcane Farming in Indonesia through DPSIR Framework." Biodiversitas Journal of Biological Diversity 21(10):4945-58.

de Resende, A. S., O. C. RP Xavier, S. de Oliveira, B. J. Urquiaga, and R. M. Boddey. Alves. 2006. "Long-Term Effects of Pre-Harvest Burning and Nitrogen and Vinasse Applications on Yield of Sugar Cane and Soil Carbon and Nitrogen Stocks on a Plantation in Pernambuco, NE Brazil." Plant and Soil 281(1-2):339-51.

Robak, Katarzyna, and Maria Balcerek. 2018. "Review of Second Generation Bioethanol Production from Residual Biomass." Food Technology and Biotechnology 56(2):174-87. doi: 10.17113/ftb.56.02.18.5428. 
Rodriguez, Orlando. 2000. "Effects of Vinasse on Sugarcane ( Saccharum Officinarum ) Productivity Effects of Vinasse on Sugarcane ( Saccharum Efecto de La Vinasa En La Productividad de La Caña de Azúcar ( Saccharum Officinarum )." Rev. Fac. Agron. (LUZ) 17(January 2000):318-26.

Rosabal, A., E. Morillo, T. Undabeytia, C. Maqueda, A. Justo, and Juan F. Herencia. 2007. "Long-Term Impacts of Wastewater Irrigation on Cuban Soils." Soil Science Society of America Journal 71(4):1292-98. doi: 10.2136/sssaj2006.0248.

Rotunno Filho, Otto Corrêa, Afonso Augusto Magalhães Araujo, Luciano Nóbrega Rodrigues Xavier, Daniel Medeiros Moreira, Rafael Carneiro Bello, Adilson Elias Xavier, and Lígia Maria Nascimento Araujo. 2014. Application of Soil Physics in Environmental Analyses: Measuring, Modelling and Data Integration.

Sadewo, L. 2017. Potensi Pemanfaatan Vinasse Cair Sebagai Substitusi Pupuk Kalium Terhadap Pertumbuhan Dan Serapan K Pada Tanaman Tebu (Saccharum Officinarum L.). Malang.

Sanchez-Lizarraga, Ana Lorena, Valeria Arenas-Montaño, Erika Nahomy MarinoMarmolejo, Luc Dendooven, Jesus Bernardino Velazquez-Fernandez, Gustavo Davila-Vazquez, Jacobo Rodriguez-Campos, Laura HernándezCuevas, and Silvia Maribel Contreras-Ramos. 2018. "Vinasse Irrigation: Effects on Soil Fertility and Arbuscular Mycorrhizal Fungi Population." Journal of Soils and Sediments 18(11):3256-70. doi: 10.1007/s11368-018-1996-1.

Santana, Veronice S., and Nádia R. C. Fernandes Machado. 2008. "Photocatalytic Degradation of the Vinasse under Solar Radiation." Catalysis Today 133135(1-4):606-10. doi: 10.1016/j.cattod.2007.12.131.

Seddik, Wafaa, Mona Osman, and Mona Kenawy. 2016. "Utilization of Vinasse and Feldspar as Alternative Sources of Potassium Fertilizers and Their Effect on Some Soil Properties and Crop Yield in Sandy Soils." Journal of Soil Sciences and Agricultural Engineering 7(9):669-75. doi: 10.21608/jssae.2016.40341.

Senthilkumar, S., T. Suganya, K. Deepa, J. Muralidharan, and K. Sasikala. 2016. "Supplementation of Molasses in Livestock Feed." 5(3):1243-50.

Siles, J. A., I. García-García, A. Martín, and M. A. Martín. 2011. "Integrated Ozonation and Biomethanization Treatments of Vinasse Derived from Ethanol Manufacturing." Journal of Hazardous Materials 188(1-3):247-53. doi: 10.1016/j.jhazmat.2011.01.096.

Soobadar, Aneeza, and K. F. Ren. Ng Kee Kwong. 2012. "Impact of High Rates of Vinasse on Some Pertinent Soil Characteristics and on Sugarcane Yield in Mauritius." Journal of Sustainable Agriculture 36(1):36-53. doi: 10.1080/10440046.2011.620226.

Stepkowska, E. T., C. Maqueda, E. Morillo, R. López, and J. L. Pérez-Rodríguez. 2001. "Changes in Physico-Chemical-Properties of Soils Fertilized by AgroIndustrial Residues." Fresenius Environmental Bulletin 10(3):300-304.

Syaichurrozi, I., Budiyono, and S. Sumardiono. 2013. "Predicting Kinetic Model of Biogas Production and Biodegradability Organic Materials: Biogas Production from Vinasse at Variation of COD/N." Bioresource Technology 149:390-97. 
Tejada, M., J. L. Moreno, M. T. Hernandez, and C. Garcia. 2007. "Application of Two Beet Vinasse Forms in Soil Restoration: Effects on Soil Properties in an Arid Environment in Southern Spain." Agriculture, Ecosystems \& Environment 119(3-4):289-98.

Umamaheswari, M., M. Jayakumari, K. Maheswari, M. Subashree, P. Mala, T. Sevanthi, and T. Manikandan. 2010. "Bioethanol Production From Cellulosic Materials." 005-011.

Valdés-Gómez, H., S. Ortega-Farías, and M. Argote. 2009. "Evaluation of the Water Requirements for a Greenhouse Tomato Crop Using the PriestleyTaylor Method ." Chilean Journal of Agricultural Research 69(1):3-11.

Velásquez-Riaño, M., Meneses-Sánchez, J. S., and Arias, C. E. C. 2019. "Evaluation of Acute Toxicity of Vinasse by Means of Daphnia Magna and Aliivibrio Fischeri: A Comparative Study." Interdisciplinary Toxicology 12(3):143.

Vlyssides, A. G., E. M. Barampouti, and S. Mai. 2005. "Wastewater Characteristics from Greek Wineries and Distilleries." Water Science and Technology 51(1):53-60.

Vyatrisa, B., S. Muhartini, and S. Waluyo. 2017. "Pengaruh Vinase Dan Macam Pupuk Organik Terhadap Pertumbuhan Dan Hasil Pak Choi (Brassica Rapa Subsp. Chinensis (L.) Hanelt)." Vegetalika 6(1):12-21.

Wei, Meng Meng, Gui Ping Xu, Hai Rong Guo, Xiao Fei Wang, and Li Jun Chen. 2014. "Effect of Vinasse Application on Soil in Sugarcane Fields." Applied Mechanics and Materials 700:270-75. doi: 10.4028/www.scientific.net/amm.700.270.

Wilkie, A. C., K. J. Riedesel, and J. M. Owens. 2000. "Stillage Characterization and Anaerobic Treatment of Ethanol Stillage from Conventional and Cellulosic Feedstocks." Biomass and Bioenergy 19(2):63-102.

Yadav, Amit Kumar, and S. Ann. 2012. "Artificial Neural Network Based Prediction of Solar Radiation for Indian Stations." 50(9):1-4.

Yang, Shang Dong, Jun Xian Liu, Jun Wu, Hong Wei Tan, and Yang Rui Li. 2013. "Effects of Vinasse and Press Mud Application on the Biological Properties of Soils and Productivity of Sugarcane." Sugar Tech 15(2):152-58. doi: 10.1007/s12355-012-0200-y.

Zali, A., M. Eftekhari, K. Pourasad, M. Ganjkhanlou, F. Fatehi, and H. Z. Pour. 2019. "Effect of Vinasse (Condensed Molasses Solubles) on Performance, Blood Metabolites, Ruminal Parameters and Carcass Characteristics of Mahabadi Goat Male Kids." Journal of Animal and Feed Sciences 28(4).

Zani, CFAS., A. D. Barneze, A. M. Robertson, C. E. P. Keith, N. P. Cerri, CC McNamara, and Cerri. 2018. "Vinasse Application and Cessation of Burning in Sugarcane Management Can Have Positive Impact on Soil Carbon Stocks." PeerJ 6:e5398. 